\title{
Labour law and social security law: social value in the modern world
}

\author{
Yelena Alexandrovna Istomina, Julia Valeryevna Ivanchina* \\ Department of Labour Law, Ural State Law University, Yekaterinburg 620137, Russia
}

\begin{abstract}
The right to work and social security is one of the basic human rights recognized by the international community. The implementation of these rights guarantees the satisfaction of socially significant needs - basic human needs (fundamental physiological needs and safety needs). Thus, a life and a development of a person, social groups and the whole society are ensured. Guarantees for the realization of the right to work and social security are especially important in times of instability and lack of confidence in the future, which is largely due to the COVID-19 pandemic. Therefore, the social value of labour law and social security law is currently increasing. The authors emphasize that most of the working-age population can satisfy socially significant needs with the help of stable employment, decent wages, safe and healthy working conditions. However, when social risks affect a person, he or she can be deprived of this opportunity. So, the satisfaction not only of fundamental physiological needs, but also of safety needs is realized with social security law.
\end{abstract}

\section{Introduction}

At the moment, when changes affect all spheres of our society, the social value of labour law and social security law is constantly increasing.

To answer the question of what this value consists in is to understand what social value is and what it is expressed in it. Of course, we understand that we are talking about a phenomenon that is of great importance and can benefit both society and people. But it must be borne in mind that the significance and usefulness of the phenomenon are the result of a subjective assessment. In other words, the society is interested or feels the need for such a phenomenon.

We should start with the fact that law is the foundation of any society, it ensures its normal functioning, allows it to develop. In addition, the law an instrument of the state, through which it fulfils its purpose - regulates public relations. Therefore, the recognition of the right and its importance for the normal life and development of the state and society itself indicates its social value. The social value of the right also involves the fact that it allows individuals to exercise their fundamental rights and freedoms, to protect them if they have been violated.

Among all human rights and freedoms, social rights are of particular importance. These rights form the basis of social development and security. Basic social rights have been recognized by the international community for many years and are enshrined in international instruments (the right to a nationality, to a family, to own property, to work, to the protection of the moral and material interests, etc.). From their diversity (without reducing the importance of some in relation to others), it is necessary to distinguish the rights, which purpose is to meet vital needs. These are such needs, without the satisfaction of which the life of a person is difficult or even impossible.

According to the theory proposed by A. H. Maslow, there are several levels of needs: fundamental physiological needs; the need for safety; the need for love; the need for esteem; the need for self-actualization. The first two levels of needs are basic, without their satisfaction, it is virtually impossible for a person to exist and develop. The three highest levels are the needs for personal growth. A person cannot experience higherlevel needs as long as he is in need of the basic ones [1].

Therefore, the satisfaction of physiological needs (food, clothing, housing) is a vital condition for the normal existence of a person. Currently, it is impossible to do this without money. For the majority of the working-age population, the source of their income is the work. Hence, the satisfaction of these needs is impossible without the labour law.

Despite the fact that we are talking about the fundamental physiological needs of the human body, they are not biological in the full sense of the word. Most of these needs can only be met with the help of funds created by the joint efforts of many people. Therefore, we say that the basic needs of a person are social in nature.

Therefore, while some scholars believe that labour law is in decline $[2,3]$, we believe that its importance is currently on the rise.

No less important, related to the basic needs, according to A. H. Maslow, is the need for safety. It 
manifests itself in the desire to get a permanent job, to have a stable income that will allow you to regularly meet the needs for food, clothing, and housing [1]. However, the need for safety, in addition to stability, implies the need to obtain social guarantees (medicine, education, pension provision), which will give confidence in the future.

The modern economy is on the verge of the fourth industrial revolution. Globalization, migration processes, and IT development lead to ambiguous results, such as changes in labour markets. The development of information technologies and Internet has a direct impact on all the society, on the development of the economy. The consequences of this process are ambiguous. Some people consider information technologies development as a danger of losing their jobs, but the others take it is a chance to work out of the office, successfully combining their work and family responsibilities [4].

Moreover, natural disasters, pandemics make everyone feel anxious for their lives, their future. Risk has become a constant companion of our life. Protection against social risks that lead to the loss of health, income, and a sense of stability is assigned to the right of social security, which also allows you to meet both physiological needs and the need for security.

\section{Results and Discussion}

The ideal of free human being, free from fear and misery, can only be accomplished if conditions are created that allow each person to enjoy their economic, social and cultural rights, as well as their civil and political rights. The fundamental economic, social and cultural rights have been recognized in international instruments, both universal and regional, and it is very important that these rights be rearmed, developed, perfected and protected [5].

Work is an indispensable condition for the development of society and the economy. The procedures and practices of employment directly affect the pace of economic development. In addition, work is the activity of transforming the resources of nature and society into material, spiritual and social goods necessary to meet the needs of man and society. Therefore, labour law is one of the branches of law that directly affects the social sphere.

Every person needs resources for his material and intellectual existence. To get them, you need to make a certain effort - to work. When a person has a permanent job, he has the opportunity to regularly provide for himself and his family with the means of subsistence. The satisfaction of this need is supported by State guarantees of wage. The need to work in healthy and decent conditions that do not cause harm to health is also important.

People spend more than a third of their active life at the workplace and contribute to the development of society. The right to the highest standards of health is recognized by society, otherwise a person cannot work, achieve well-being. If life in the workplace is jeopardized, the foundation for productive employment and socio-economic development is lost. The right of a person to protect his health and life at the workplace is not only included in the scope of labour law, but is also considered as one of the basic human rights. "All workers have the right to safe and healthy working conditions", fixed in the European Social Charter (Turin, October, 18th, 1961).

Working conditions have a direct impact on the human body. Therefore, the ability to work and earn money for as long as possible is directly dependent on the conditions at the workplace. Ensuring decent working conditions is a socially significant need. Its satisfaction is possible by using norms of labour law.

Human health at the state level is integrated into the health of the nation and becomes an important factor in economic development. The World Health Organization underlines that fair employment and decent work are important social determinants of health, and a healthy workforce is an essential prerequisite for productivity and economic development. Occupational health is closely linked to public health and health system development [6].

Of course, labour law is able to meet socially significant needs. The right to health protection, to social security, and to pensions benefits is also closely linked to work. Employees are covered by all types of mandatory social insurance - from accidents at work and occupational diseases, in case of temporary disability, of maternity, mandatory pension (old age, disability, survivor pension) and basic healthcare insurance.

The right to work presupposes the ability to work and to meet one's needs. But sometimes it is difficult or even impossible to do this. If a person becomes ill, if he needs to take care of a small child or an elderly relative, if he is unemployed, he cannot do without outside support, and it is not always possible to get such support from the family or the immediate environment. Labour law regulates the intense activity of people, creates guarantees of safe work and stable wages. However, when a person cannot work, this legislation does not achieve its goal. Then social security law guarantees people support in the form of various benefits and pensions [7].

Protecting a person from social risks is the goal of social security law. At such times, the social value of this branch of law is obvious. The understanding of the need for this appeared later than the need for labour regulation, but already in the middle of the twentieth century, international organizations - the United Nations, the International Labour Organization, and later the Council of Europe, recognized the right to social security as a fundamental human right.

According to the Universal Declaration of Human Rights (proclaimed by the United Nations General Assembly in Paris on December 10th, 1948 (General Assembly resolution $217 \mathrm{~A}$ )), everyone has the right to a standard of living adequate for the health and well-being of himself and of his family, including food, clothing, housing and medical care and necessary social services, and the right to security in the event of unemployment, sickness, disability, widowhood, old age or other lack of livelihood in circumstances beyond his control. The 
European Social Charter specifies that all workers and their dependents have the right to social security; anyone without adequate resources has the right to social and medical assistance, to benefit from social welfare services.

"No doubt," A. Maslow pointed out, "physiological needs dominate all others. A person who is lacking food, security, love, and esteem would most probably hunger for food more strongly than for anything else. If all the needs are unsatisfied, and the organism is dominated by physiological needs, all others may become simply nonexistent or be pushed into the background" [1].

Social security law also deals with the satisfaction of basic needs. The provision of pensions and benefits as compensation for lost earnings is most often a guarantee of maintaining a normal human life. However, the right to social security is not limited to payments. It is not just about a person's physical survival.

The need to restore the health of a sick person, to rehabilitate a disabled person, is not only material. For example, rehabilitation of disabled people is aimed at eliminating or maximally compensating for the limitations of life activity for social adaptation, for achieving financial independence and for integration into society. This process is primarily aimed at meeting the need for security, confidence in the future. Its purpose is to allow a person with disabilities to provide for themselves and their family with means of subsistence, to live independently, to interact with other people.

In addition, many citizens can receive various social services. Social and psychological services involve assistance in correcting the psychological state of individuals. Social and pedagogical services are aimed at the prevention of behavioural deviations, the development of positive interests, and the organization of leisure activities. Social services should help families raise their children and improve communication opportunities for people with disabilities, including children with disabilities. We believe that these services are also aimed at meeting the need for security, not only for individuals themselves, but also for their families, and even for society. The correct formation and satisfaction of the needs of the individual is of great social importance. This process is an urgent task for both society and the state, which has declared itself social.

Thus, the right of social security is designed to protect a person from the negative consequences of social risk in various ways, which indicates its social value not only for people, but also for society.

The social value of social security law is also due to the fact that it encourages people to work in informal economy, to take care of their well-being both during the period when they are independent and able to work, and during the period when they find themselves in a situation of social risk. For example, the size of most pension benefits is closely related to the length of employment period and the size of the employee's salary. The individual pension coefficient - the basis for calculating the insurance pension - directly depends on the insurance premiums paid for the employee. So, the formalization of the labour social value in social security law corresponds to the constitutional principles, as well as the international standards on human rights [8].

In case of illness or injury, an employee can claim a temporary disability benefit, the amount of which also directly depends on both the amount of salary and the duration of work. This approach is also supported by international social security standards. For example, the ILO Medical Care and Sickness Benefits Convention C130 (1969) claims that the employee has the right to sickness benefit. The total of this benefit and any other means shall be sufficient to maintain the family of the beneficiary in health and decency. This means that the rate of the benefit, increased by the amount of any family allowances payable during the contingency, shall be at least 60 per cent of the total of the previous earnings of the beneficiary and of the amount of any family allowances payable to a person protected.

There are also payments that are not related to any length of service, salary, or contributions. These are social pensions. The State undertakes to provide minimum pension benefits to citizens who have no seniority and have not made pension contributions. For example, these are workers in the informal economy. However, the amount of such payments is usually much less. This is due to the fact that the state determines the socially significant needs that need to be met, taking into account the balance of interests of citizens and society.

At the same time, new social conditions often give rise to new rules. Today, the right to social security cannot be limited to protecting only employees and their family members. The ILO Social Protection Floors Recommendation R202 (2012) establishes a broader approach. ILO underlines that the right to social security is a human right, but it is, along with promoting employment, an economic and social necessity for development and progress. So, some new principles of social security should be implemented, such as universality of protection, based on social solidarity; social inclusion, including of persons in the informal economy; financial, fiscal and economic sustainability with due regard to social justice and equity; coherence with social, economic and employment policies. It is recommended for all ILO members to formulate and implement national social security extension strategies, including basic social security guarantees which secure protection aimed at preventing or alleviating poverty, vulnerability and social exclusion. This means that issues of protection of self-employed citizens, employees of various platforms, should be recognized as the responsibility of the state, employers, trade unions, and the entire society. In addition, there is a question of recognizing new circumstances as social risks.

It should also be noted that the economic and social changes currently impacting on state welfare lead to the emergence of what may be termed "new social risks" as part of the shift to a post-industrial society. These concern access to adequately paid employment, particularly for lower-skilled young people, in an increasingly flexible labour market, and managing worklife balance for women with family responsibilities engaged in full-time careers [9]. Of course, new social 
risks require attention and governance, and it must be, first of all, new regulation of social security.

Thus, the willingness to recognize the emergence of new social risks and to protect people from them through social benefits once again demonstrates the social value of the right to social security. For example, when the world was hit by the COVID-19 pandemic in 2020, total restrictions left many people without jobs or livelihoods. In 2020 global hours actually worked during the year fell by nearly 9 per cent by comparison with the last quarter of 2019. This is the equivalent of the loss of 255 million full-time jobs. Nearly half of the working hour losses were attributable to loss of employment: 33 million people became unemployed; while many more - 81 million - left labour markets and became inactive. The other half was the result of people working fewer hours or no hours at all - but staying in their employment relationship. With regard to jobs, the impact was four times greater than that of the financial crisis in 2008. The ILO calls this statistic staggering [10].

It took enormous financial resources not only to provide medical care to persons sick with COVID-19, but also to pay benefits to families with children and people who lost their jobs. States that guarantee social security have essentially taken the first hit in the face of the pandemic. This was made possible by effective State social security systems.

In Russia, workers over the age of 65 were quarantined; they received sickness benefits during this entire period - almost a year. Such benefit shows not only the general significance of the legislation on social security, but also the advantages of the Russian system of compulsory social insurance.

In contrast, for example, to the American system, where there is no unified state-guaranteed system of benefits for temporary disability. As the World Health Organization notes, the absence of paid sick days forces ill workers to choose between caring for their health or losing the jobs that support their families. Paid sick leave is especially critical in times of crisis when workers fear dismissal and discrimination if they call in sick. Yet the United States is virtually alone in providing no federally mandated paid sick time or paid family leave. Private provision of these benefits follows predictable patterns of inequality. Although some states have adopted paid leave programs, these are recent and partial [11].

It was during that period, in April of 2020, that the sickness benefits minimum amount was established not less than the minimum wage for a full month. The unemployment benefit during that period was also set at a higher level than usual. This allowance was increased for persons with minor children. In the spring of 2020, new benefits for families with children appeared. They were paid until 2021, and some of them remain important.

The measures taken by the state indicate not only the high social profile of the state, but also the consideration of socially significant needs of both individuals and the whole society. The right of social security, through which all these measures were implemented, once again confirmed its social value.

\section{Conclusions}

Not all the needs of society, its individuals and the process of their satisfaction require legal regulation. Many needs go without any legal impact. Only important - socially significant needs of society and individuals acquire special significance and are mediated by law. Basic needs (physiological needs and the need for security) are socially significant - necessary for the existence of a person, social groups and the entire society. Their satisfaction alone is impossible. They are based on the needs necessary to make up for the lack of life benefits, for the preservation and development of a person, social groups and society. Meeting these needs is impossible without entering into social relations and fixing them in the rules of law - including labour law and social security law.

We assume that it is the implementation of the rules of labour law that allows a person to satisfy both physiological needs and the need for safety to the maximum extent. In the event of a social risk that has led to adverse consequences, as a result of which a person loses the ability to independently meet their vital needs, their compensation becomes possible by referring to the rules of social security law.

This not only confirms the stated thesis that these branches of law have a social value for modern society, but also indicates their combined importance for the qualitative satisfaction of socially significant needs, both for individuals and for society as a whole. However, this does not reduce the social value of these branches of law.

\section{References}

1. A. H. Maslow, A Theory of Human Motivation (Peter, St. Petersburg, 2008)

2. C. L. Estlund, Annual Review of Law and Social Science, 2(1), 105-123 (2006). DOI: https://doi.org/10.1146/annurev.lawsocsci.2.081805. 110015

3. S. Deakin, Jerusalem Review of Legal Studies, 16(1), 28-39 (2017). DOI: https://doi.org/10.1093/ jrls/jlx016

4. J.V. Ivanchina, Y.A. Istomina, Proceeding of the International Science and Technology Conference "FarEastCon 2019". Smart Innovation, Systems and Technologies, 172, 813-824 (2020). DOI: https://doi.org/10.1007/978-981-15-2244-4_77

5. G. Stürmer, Novos Estudos Jurí-dicos, 24, 721-735 (2019)

6. WHO Global Plan of Action on Workers' Health (2008-2017): Baseline for Implementation. Global Country Survey 2008/2009. Executive Summary and Survey Findings (Geneva, April 2013). Retrieved from: https://www.who.int/ occupational health/who_workers health_web.pdf

7. Y.A. Istomina1, J.V. Ivanchina, Advances in Social Science, Education and Humanities Research, 498, 
129-134 (2020). DOI: https://doi.org/10.2991/ assehr.k.201205.023

8. M. Yu. Fedorova, Advances in Social Science, Education and Humanities Research, 498, 91-100 (2020). DOI: https://doi.org/10.2991/assehr.k. $\underline{201205.017}$

9. P. Taylor-Gooby, International Social Security Review, 57, 45-64 (2004). DOI: https://doi.org/ 10.1111/j.1468-246X.2004.00194.X
10. Work in the time of COVID: Report of the DirectorGeneral International Labour Conference 109th Session (2021). Retrieved from: https://www.ilo.org/wcmsp5/groups/public/--ed norm/--relconf/documents/meetingdocument/wcms 793265 .pdf

11. C. Albiston, C. Fisk, L. Rev. Calif. L. Rev. Online, 5 (2020). Retrieved from: https://www.california lawreview.org/covid-19-holes-in-us-social-safetynet. 